\title{
An assessment of the quality and use of rainwater as the basis for sustainable water management in suburban areas
}

\author{
Monika Zdeb ${ }^{1, *}$, Dorota Papciak $^{1}$, Justyna Zamorska ${ }^{1}$ \\ ${ }^{1}$ Department of Water Purification and Protection, Faculty of Civil and Environment Engineering and \\ Architecture, Rzeszów University of Technology
}

\begin{abstract}
A common economic use of rainwater is the basis for strategies that will allow the water sector to adapt to progressive climate change. Rainwater is a basic part of water resources that ensures the renewal of the surface and groundwater, therefore they should be protected against pollution and be managed and used in places of rainfall. This is particularly true for heavily urbanized, agricultural and industrial areas. Stormwater collection and storage systems have been introduced in many countries [1]. The water obtained in this way is a valuable source of fresh water, thanks to which it is possible to reduce the demand for tap water by almost $60 \%$ or use it during periods of drought $[1,2]$. The idea of the sustainable management of water resources and the increasing ecological consciousness of society have allowed installations for the collection and use of rainwater in residential houses and public buildings to become an increasingly popular phenomenon [3, 4]. The research and assessment of rainwater quality is a guarantee of safety for its users. The article presents the results of research on the physical and chemical quality of rainwater collected directly from precipitation. Samples for research were collected in a suburban area during March-November 2015. The pH, turbidity, permanganate index, OWO, nitrogen compounds, phosphates, oxygen content, acidity, basicity, conductivity, hardness, and heavy metals content were determined. The obtained results were the basis for indicating the possibility of using rainwater for various economic purposes.
\end{abstract}

\section{Introduction}

Currently, about $36 \%$ of the world's population faces a crisis related to the lack of water. There are many areas where, as a result of limited access to freshwater resources, it is impossible to cover the ever-growing demand for this resource. It is believed that countries with a water supply below $2000 \mathrm{~m}^{3} \cdot \mathrm{M}^{-1}$ may have difficulty meeting the needs of the population, and countries with resources below $1000 \mathrm{~m}^{3} \cdot \mathrm{M}^{-1}$ are considered as areas with deep water deficits.

In Poland, the biggest problem of water management is the significant variability of atmospheric precipitation and extreme hydrological phenomena, most noticeable in large

* Corresponding author: mzdeb@prz.edu.pl 
agglomerations and agricultural areas [5].

Rainwater collection and storage systems have been introduced in many countries. The waters obtained in this manner are a valuable source of fresh water, thanks to which the demand for tap water can be reduced and used during periods of drought [1]. The leaders in creating such systems for collecting and using rainwater include Germany, India, Japan, Great Britain and Australia [6]. Rainwater collection techniques are used worldwide to support the drinking water supply [4, 6], manage rainwater and reduce the risk of flooding by reducing the volume of water flow in storm water systems [2]. They are also one of the elements of the efficient and ecological functioning of buildings [7]. In areas with dispersed buildings where the costs of constructing classic water supply systems are high, the RWHS (Rain Water Harvested System) has proved to be an affordable and sustainable alternative [8] of drinking water supply.

Rainwater in households can be used, among others, for rinsing sanitary facilities, washing, cleaning, watering lawns and crops as well as car washing. Rainwater, in areas particularly exposed to water deficits, are also considered in terms of water intended for consumption, among others in Kenya and Bangladesh [9]. Therefore, knowledge about the quality of collected waters is crucial for the protection of public health.

The quality of rainwater obtained is characterized by considerable spatial and temporal variability. The composition of rainwater may be dependent on many factors, among others: pollution of the atmosphere (including the presence of dust, plant pollen, bioaerosol), catchment type, land development (industrial areas, roads and highways), local microclimate and nature trailing surface (roofs with different inclination, covered with different materials). The most contaminated rainwater occurs in urbanized areas, which is mainly related to the emissions of power plants, local boiler houses and industry [10].

Although it is commonly believed that rainwater is relatively clean, the results obtained testify to its physicochemical and microbiological contamination [11]. Water quality is a very important feature from the point of view of the possibility of its use in the economy; however it does not always have to be water of the highest quality. Nevertheless, not all of the activities performed with water require its highest quality. Analysis of the structure of water consumption for household and residential purposes in residential houses shows that about $50 \%$ of drinking water can be replaced by rainwater, and in public buildings nearly $65 \%$ [12].

The aim of the study was to examine the physicochemical quality of rainwater collected in suburban areas and to assess the possibility of using these waters for various economic purposes, and also as an alternative source of drinking water supply in crisis conditions.

\section{Research methodology}

The research was conducted in 2015 on a non-industrialized suburban area in the following seasons: spring (March-May), summer (June-August) and autumn (September-November). Analyses were carried out for rain water taken from guttering of buildings with various roofing materials: concrete tile $(B)$, ceramic tile $(C)$, galvanized sheet $(\mathrm{O})$ and terrace covered with epoxy resin (T). Samples for research were collected during selected rain events, guided by the intensity of precipitation, as well as after rejecting the so-called first runoff. The control test was rainwater, which had no contact with the roof surface and was taken directly from atmospheric precipitation $(\mathrm{P})$. In the immediate vicinity of the place of sampling in households, homes are heated using gas furnaces or high-efficiency solid fuel stoves.

Selected physical and chemical parameters were determined in accordance with the standards set out in Table 1, applicable procedures and standards applicable to the study of surface and groundwater. 
The assessment of corrosive aggressiveness in water distribution and storage systems was made based on the current PN-EN 12502 standard "Protection of metal materials against corrosion" and the now-obligatory standard N-72/C-04609 "Water and sewage Initial qualitative assessment of the corrosive effect of cold natural waters on pipes made of cast iron, ordinary or galvanized steel".

Table 1. Scope and methodology for the determination of physicochemical properties for the investigated rainwater.

\begin{tabular}{|l|l|}
\hline \multicolumn{1}{|c|}{ Tested parameter } & \multicolumn{1}{c|}{ Method / standard } \\
\hline $\mathrm{pH}$ & electrometric method; PN-EN ISO 10523: 2012 \\
\hline conductivity & electrometric method; PN-EN 27888: 1999 \\
\hline turbidity & nephelometric method; PN-EN ISO 7027: 2003 \\
\hline hardness & titrimetric, complexometric method; PN-ISO 6058: 1999 \\
\hline basicity & titration method; PN-EN ISO 9963-1: 2001 \\
\hline acidity & titration method; PN-C-04547-01: 1974 \\
\hline aggressive CO2 & the Geier method in a marble sample; PN-C-04547-03: 1974 \\
\hline the permanganate index & The permanganate method; PN-ISO 6060: 2006 \\
\hline $\begin{array}{l}\text { ammonium ion, nitrite nitrogen, nitrate } \\
\text { nitrogen, phosphates, sulphates, chlorides }\end{array}$ & Ion chromatography method, PN-EN ISO 10304-1: 2009 \\
\hline Total Organic Carbon (TOC) & Sievers 5310 C TOC analyzer; PN-EN 1484: 1999 \\
\hline $\begin{array}{l}\text { heavy metals: copper, lead, chromium, } \\
\text { nickel, zinc; }\end{array}$ & $\begin{array}{l}\text { X-ray spectrometry method; procedures for the PICOFOX } \\
\text { apparatus }\end{array}$ \\
\hline
\end{tabular}

\section{Results and discussion}

\subsection{The quality of rainwater}

Parameters that most often describe the quality of rainwater are $\mathrm{pH}$ and turbidity. The lowest $\mathrm{pH}$ values were recorded for rainwater taken directly from atmospheric precipitation. Rainwater tests from strongly urbanized zones indicate much lower $\mathrm{pH}-4.4$ [13]. Among rainwater collected from various roofing materials, the lowest rainfall was characterized by rainwater collected from the roof covered with a galvanized sheet. The increase of $\mathrm{pH}$ in water collected from concrete tiles in relation to rainwater collected directly from the air results from the composition of cement, which includes carbonates, e.g. calcium carbonate $\left(\mathrm{CaCO}_{3}\right)$, magnesium carbonate $\left(\mathrm{MgCO}_{3}\right)$, which can to some extent be washed out by rainwater and raise the $\mathrm{pH}[14]$.

Studies carried out so far indicate that $\mathrm{pH}$ values may undergo seasonal changes. Lee et al. showed that the average $\mathrm{pH}$ reaches higher values in the spring and summer, while Leong et al. stated that the reaction is reduced in the summer and winter months. The reason for this phenomenon is the increased content of nitrogen and sulfur compounds that get into the atmosphere as a result of the combustion of liquid and fossil fuels $[15,16,17]$.

Rainwater collected from various roofing materials was characterized by the greatest turbidity in the summer season. Water collected from the terrace covered with epoxy resin approx. 8 NTU characterized by the highest turbidity. For rainwater collected in spring and summer, there is a tendency to increase turbidity after contact with the roof surface. 

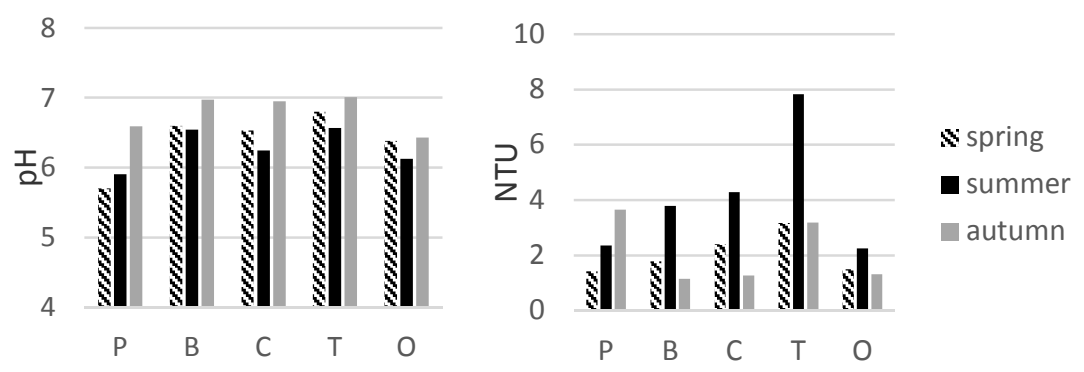

Fig. 1. The $\mathrm{pH}$ and turbidity rainwater.

Reverse relations are observed in the autumn season. Leong et al. [14] also show the possibility of detaining pollutants from rainwater on rough surfaces. For roof surfaces made of glass, metal and ceramics, respectively: 93 NTU, 57 NTU, 10 NTU were determined [14].

In the case of water taken directly from the air, the turbidity was close to 4 NTU. Naddeo et al. [18] provide much higher turbidity values for rainwater collected directly from the air: 25.88 NTU. This may be due to the fact that the cited studies were conducted in the urban zone [18]. The turbidity of rainwater can also be the result of proliferating bacteria [19]. The content of nitrogen compounds for all tested rain water was at a similar level (Fig. 2).
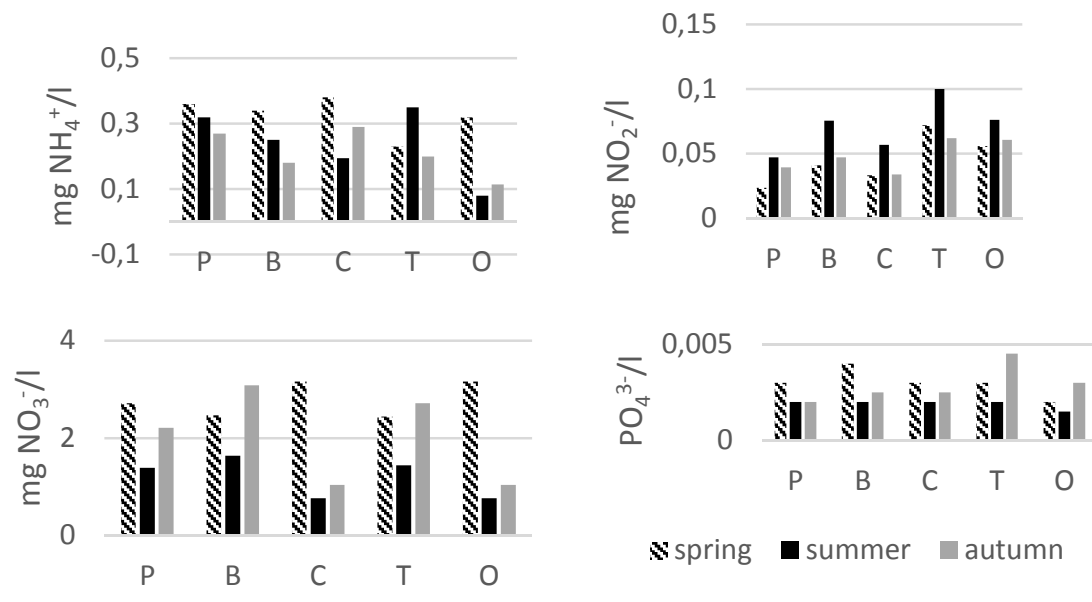

Fig. 2. Content of biogenic compounds in rainwater.

The median values of ammonium nitrogen concentrations were within the range of 0.20-0.35 $\mathrm{mg} \mathrm{NH}_{4}{ }^{+} / 1$, respectively for rainwater taken from galvanized sheet and for rainwater harvested directly from the roof covered with ceramic tiles. Significantly lower values were obtained in rainwater surveys collected in urbanized areas - $0.02 \mathrm{mg} \mathrm{NH}_{4}{ }^{+} / 1$ [20]. The highest concentrations of nitrite were determined in rainwater taken from the terrace $(0.1 \mathrm{mg} \mathrm{N} / \mathrm{l})$, and the lowest in rainwater washing the ceramic tile $(0.025 \mathrm{mg} \mathrm{N} / \mathrm{l})$. The highest nitrate concentrations were recorded for water from a roof covered with concrete and ceramic tiles. Similar concentrations of nitrates (V), determined in rainwater collected from a roof covered with concrete tiles, were designated in highly urbanized areas [20].

The lowest amount of phosphates was found in rainwater harvested from galvanized steel, and the largest in water washing the resinous terrace. The slightly higher values were received by Duncan et al. [22] in rainwater from the urban zone - 0.01-0.10 $\mathrm{mg} \mathrm{PO}_{4}^{3-} / 1$. The 
source of biogenic compounds in rainwater from atmospheric air may be pollen, fungal spores, cells and bacterial spores, as well as other substances originating, for example, from agricultural crops that pollute roof surfaces in the dry deposition process. In addition, biogenic compounds may also come from natural sources such as bird droppings, bryophytes and lichen contaminating roof runners [21]. The greater the surface roughness and the smaller the slope of the surface, the more problems with rinsing and the greater likelihood of accumulation of these impurities [22].

Differences in the amount of phosphates and nitrogen compounds between water taken from the different roof surfaces may result primarily from the structure of these surfaces and the possibility of rinsing dry deposition contaminants.

Total organic carbon (TOC) is a summary parameter describing the degree of water pollution by organic matter. The highest median values of TOC content, as in the case of permanganate index, characterized the rainwater taken from the terrace $-5 \mathrm{mg} \mathrm{C} / \mathrm{l}$ (Fig. 3).
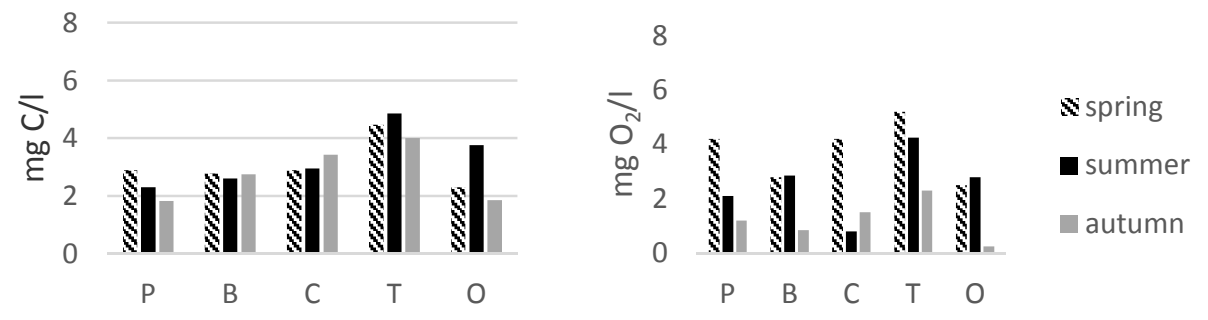

Fig. 3. The content of total organic carbon and the permanganate index of rainwater.

This illustrates the correlation between these parameters. Similar results were obtained in other studies $-4.79 \mathrm{mg} \mathrm{O} / 1$ and $5.92 \mathrm{mg} \mathrm{C} / 1$. These were the indications of the highest of the roof surfaces tested. The conduction median values for rainwater harvested from different roof coverings and directly from the air fluctuated in the range from just over 1 to $26 \mu \mathrm{S} / \mathrm{cm}$, and the center values from 1 to $4 \mu \mathrm{S} / \mathrm{cm}$ (Fig. 4 ).

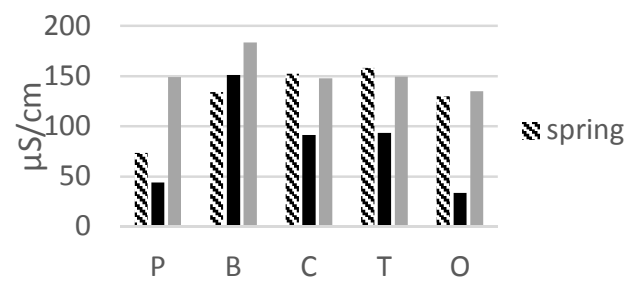

Fig. 4. Electrical conductivity values in rainwater.

The lowest conductivity indications were noted for water collected from the guttering of the roof covered with galvanized sheet (similarly to the control sample taken directly from atmospheric precipitation). It has not been clearly demonstrated for which of the waters the parameter assumes the highest values. Similar results for waters collected from roofs covered with tiles and sheet metal were given to Zhang et al. [24], and much higher conductivity was determined for run-offs from the so-called green roof [23]. The total mineralization of rainwater in natural conditions can be only a few milligrams of substances dissolved in one liter of water; however, in the industrialized regions the degree of mineralization is increased. The obtained values are relatively low compared to those obtained for industrialized zones - $614.8 \mu \mathrm{S} / \mathrm{cm}[13]$. 


\subsection{Corrosion properties of rainwater}

Assessment of corrosive properties of rainwater in terms of economic use is very important, because water of good quality, in relation to sanitary regulations, can be aggressive water, which brings about large economic losses. Rainwater, due to its insignificant hardness, low alkalinity and $\mathrm{pH}<7$, is considered to be water with increased corrosive aggressiveness.

Based on the determined chemical parameters and indicators of the corrosivity of rainwater, it was found that regardless of the method of rainwater collection, they show enhanced corrosion properties in relation to cast iron and ordinary and galvanized steel (Table 2).

Table 2. Values of parameters describing the corrosive properties of rainwater in accordance with the PN-EN 12502 and N-72/C-04609 standard for various roofing materials (summer 2015).

\begin{tabular}{|c|c|c|c|c|c|c|c|}
\hline \multirow{2}{*}{ Parameter } & \multirow[b]{2}{*}{ Unit } & \multicolumn{5}{|c|}{ Middle values in rainwater } & \multirow[b]{2}{*}{$\begin{array}{c}\text { Parameter } \\
\text { values for } \\
\text { water with } \\
\text { reduced } \\
\text { corrosive } \\
\text { properties }\end{array}$} \\
\hline & & $\mathbf{P}$ & $\mathbf{B}$ & $\mathbf{C}$ & $\mathbf{T}$ & $\mathbf{O}$ & \\
\hline Langerier index & - & $-4,09$ & $-3,33$ & $-3,70$ & $-4,04$ & $-3,89$ & from -0.5 to 0.5 \\
\hline $\begin{array}{l}\text { aggressive carbon } \\
\text { dioxide }\end{array}$ & $\mathrm{mg} / \mathrm{dm}^{3}$ & 0,8 & 1,1 & 1,0 & 0,8 & 0,7 & 0,0 \\
\hline basic alkalinity & $\mathrm{mval} / \mathrm{dm}^{3}$ & 0,08 & 0,14 & 0,08 & 0,14 & 0,12 & $>2,14$ \\
\hline calcium hardness & $\mathrm{mval} / \mathrm{dm}^{3}$ & 0,16 & 0,20 & 0,20 & 0,18 & 0,18 & $>2,14$ \\
\hline $\begin{array}{l}\text { electrolytic } \\
\text { conductivity }\end{array}$ & $\mu \mathrm{S} / \mathrm{cm}$ & 1,0 & 2,0 & 2,5 & 2,0 & 1,0 & $<1000$ \\
\hline $\begin{array}{l}\text { permanganate } \\
\text { index }\end{array}$ & $\mathrm{mgO}_{2} / \mathrm{dm}^{3}$ & 4,0 & 2,5 & 2,5 & 3,0 & 4,0 & $<80$ \\
\hline dissolved oxygen & $\mathrm{mgO}_{2} / \mathrm{dm}^{3}$ & 10,0 & 10,0 & 11,0 & 9,5 & 10,0 & $>6$ \\
\hline sulfur & $\mathrm{mgSO}_{2}{ }^{-} / \mathrm{dm}^{3}$ & 1,2 & 2,1 & 2,5 & 2,4 & 1,5 & $<50$ \\
\hline chloride & $\mathrm{mgCl} / / \mathrm{dm}^{3}$ & 3,0 & 2,0 & 2,0 & 2,0 & 2,3 & $<150$ \\
\hline nitrates & $\mathrm{mg} / \mathrm{dm}^{3}$ & 1,5 & 2,5 & 2,1 & 2,5 & 1,3 & $<62$ \\
\hline ammonium ions & $\mathrm{mgNH}_{4}{ }^{+} / \mathrm{dm}^{3}$ & 0,35 & 0,3 & 0,25 & 0,25 & 0,2 & $<20$ \\
\hline
\end{tabular}

\subsection{Heavy metals in rainwater}

In each of the tested waters, traces of nickel, chromium and lead in concentrations not exceeding $10 \mu \mathrm{g} / \mathrm{l}$, copper ions in amounts up to $20 \mu \mathrm{g} / \mathrm{l}$ and zinc in amounts often significantly exceeding $100 \mu \mathrm{g} / \mathrm{l}$ were recorded (Table 3 ). The water collected from the roof covered with galvanized sheet is distinguished by a significantly higher zinc content $(3164,55 \mu \mathrm{g} \mathrm{Zn} / \mathrm{l})$ than in the other samples (below $1000 \mu \mathrm{g} \mathrm{Zn} / \mathrm{l}$ ). This dependence on roofing was also indicated by other researchers [16, 24].

For rainwater harvested directly from precipitation, the highest concentrations of heavy metals were recorded in the spring. However, for rainwater after contact with roof surfaces, no significant correlation was observed with seasonality. They are most visible in heavily industrialized and densely built-up areas [13]. 
Table 3. Concentrations of selected heavy metals in rainwater rainwater.

\begin{tabular}{|c|c|c|c|c|c|c|}
\hline \multirow[t]{2}{*}{ Rainwater } & \multirow{2}{*}{ Research season } & \multicolumn{5}{|c|}{ Concentration of metal ions $[\mu \mathrm{g} / \mathrm{l}]$} \\
\hline & & copper & zinc & nickel, & lead & chromium \\
\hline \multirow{3}{*}{$\mathrm{P}$} & spring & 18,008 & 116,14 & 3,755 & 1,88 & 2,001 \\
\hline & summer & 15,867 & 265,119 & 1,712 & 1,746 & 1,107 \\
\hline & autumn & 5,453 & 1692,823 & n.d. & n.d. & n.d. \\
\hline \multirow{3}{*}{ B } & spring & 9,161 & 36,202 & 1,205 & 0,811 & 0,512 \\
\hline & summer & 3,587 & 12,626 & 0,45 & n.d. & 0,527 \\
\hline & autumn & 12,315 & 36,059 & n.d. & n.d. & n.d. \\
\hline \multirow{3}{*}{$\mathrm{C}$} & spring & 8,662 & 151,011 & 1,233 & n.d. & 1,587 \\
\hline & summer & 4,65 & 18,084 & 0,449 & 0,683 & 0,431 \\
\hline & autumn & 6,647 & 58,416 & n.d. & n.d. & n.d. \\
\hline \multirow{3}{*}{$\mathrm{T}$} & spring & 6,219 & 543,18 & 2,099 & n.d. & 2,57 \\
\hline & summer & 7,147 & 405,864 & 0,76 & n.d. & 0,974 \\
\hline & autumn & 5,967 & 1499,275 & n.d. & n.d. & n.d. \\
\hline \multirow{3}{*}{$\mathrm{O}$} & spring & 6,474 & 4125,146 & 1,76 & 9,144 & 1,39 \\
\hline & summer & 11,214 & 1933,59 & 1,853 & n.d. & 0,877 \\
\hline & autumn & 3,967 & 27354,518 & n.d. & 5,111 & n.d. \\
\hline
\end{tabular}

n.d. not detected

\section{Conclusions}

Results of this study allow for the following conclusions:

- The rainwater tested was characterized by: $\mathrm{pH}$ in the range 5.5-7.5, turbidity of 1.5-8.0 NTU, low alkalinity, trace hardness and the presence of aggressive carbon dioxide.

- The quality of rainwater depends on the surface of the runoff and the method of its collection. Rainwater collected from the roof covered with galvanized sheet was characterized by the lowest $\mathrm{pH}$ (about $\mathrm{pH}$ 6.0) and the lowest turbidity in relation to the water collected from the other roof surfaces (concrete tile, ceramic tile, terrace covered with epoxy resin). The most polluted was the water collected from the terrace covered with epoxy resin, which confirms the fact that surfaces with a small angle of inclination cause accumulation of pollution, worsening the quality of rainwater.

- The obtained research results do not allow a clear determination on the impact of the season on the physical and chemical quality of rainwater. This may result from the low level of urbanization of the area where the research was carried out (suburban area) and the class of boilers used for heating homes in the area of sampling

- The determined chemical parameters and indicators of the corrosivity of rainwater show enhanced corrosion properties of these waters irrespective of the season of the year and the method of collection. Due to low alkalinity and $\mathrm{pH}>7$, they will cause uniform corrosion. The smallest risk of uniform and pitting corrosion occurs for waters collected from roofs covered with concrete and ceramic tiles. The tested rainwater, due to hardness below $1 \mathrm{mg} \mathrm{CaCO}_{3} / 1$, is characterized by leaching aggressiveness against 
ordinary concrete. Roofing made of cement and ceramic mixtures reduce the corrosive aggressiveness of rainwater, but do not eliminate it.

- As a result of the analysis, it was found that rainwater is a promising alternative to water resources, and after prior treatment they may be considered as an emergency source of water supply for consumption under crisis conditions. The process of treating rainwater in terms of its consumption should be directed to the removal of turbidity, deacidification by correction of the reaction with simultaneous increase in alkalinity.

- The tested waters can be used to meet the needs for water of lower quality, among others for cleaning, washing cars, flushing toilets and for irrigating crops and watering lawns without adversely affecting vegetation and soil organisms.

\section{Reference}

1. D. Słyś DWE Dolnośląskie Wydawnictwo Edukacyjne, (2013)

2. D. Słyś, A. Stec, Ecol. Chem. Eng. S 21, 623-635 (2014)

3. S. Ward, F. A. Memon, D. Butler, Water Research, 46, 5127-5134, (2012)

4. Y. Zhang, A. Grant, A. Sharma, D. Chen, L. Chen, Water Resour Manage, 24, (2010)

5. M. Jones, W. Hunt, Resour. Conserv. Recy. 54, 623-629, (2010)

6. Z. Kundziewicz, K. Juda-Rezler, Nauka 4, 69-76 (2010)

7. M. Jones, W. Hunt, Resour. Conserv. Recy.; 54, 623-629, (2010)

8. Basinger M. Basinger, F. Montalto, U. Lall., J. Hydrol., 392, 105-118, (2010)

9. M. Kimani, N. A. Gitau, D. Ndunge, Inter. J. of Eng. And Science, 5, 39-49. (2015)

10. S.Evans, P. Huxley, C. Gately, M. Webber, A. Mears, S. Pajak, J. Medina, T. Kendall, C. Katona., Br. J Psychiatry, 188, 75-80, (2006)

11. C. K. Despins, K. Farahbakhsh, C. Leidl., J. Water Supply Res. Technol. AQUA 58:117-134, (2009)

12. W. Gwezi, N. Dunjana., C. Pisa., T. Tauro., G. Nyamadzawo, Sustainability of Wat. Qualit and Ecol., 6,107-118, (2015)

13. A. Ludwińska., J. Paduchowska, Rynek Instalacyjny, 5, 42-46, (2017)

14. L. Bai, Z. Wang, Journal of Geochemical Exploration, 137, 65-72, (2014)

15. J. Leong, S. Phaik E. Meng N., J. of Cleaner Product. 142, 3014-3027, (2017)

16. A. Jarosiewicz, Inż, Ecol., 29, 48-56, (2012)

17. J. Y. Lee, J. S. Yang, M. Han., J. Choi, Science of the Total Environment, (2010).

18. V. Naddeo, D. Scannapieco., V. Belgiorno, Journal of hydrology, 498, 287-291, (2013)

19. Q. Ding., A. Schweiger.,M. L'Heureux, D. Battisti., S. Po-Chedly, N. Jonshon, E. Blanchard - Wrigglesworth, K. Harnos, Q. Zhang, R. Estman, E. Steig, Nature Climate Change, 7, 289-295, (2017)

20. J. Y. Lee, G. Bak, M. Han, Environmental Pollution, 162, 422-429, (2012)

21. H. P. Duncan, Cooperative research centre for catchment hydrology, Melbourne, Australia, ISPN 1-876-00606-4 (1995)

22. G. J. Wilbers, Z. Sebesvaria, A. Rechenburgb, Environ Pollution, 182, 225-232, (2013)

23. Q. Zhang, X. Wang, P. Hou, W. Wan, R. Li, Journal of Environmental Management, 132, 178-187, (2014)

24. C. B. Mendez, J. B. Klenzendorf, B. R. Afshar, M. T. Simmons, M. E. Barrett, K. A. Kinney, M. J. Kirisits, Water Research 45, 2049 -2059, (2011) 